\title{
Habitat related differences in the survivorship and growth of juvenile sea urchins
}

\author{
N. L. Andrew* \& J. H. Choat \\ Leigh Marine Laboratory and Zoology Department, University of Auckland, Auckland, New Zealand
}

\begin{abstract}
In northeastern New Zealand abundance of the echinoid Evechinus chloroticus is strongly linked to habitat. A survey of both adults and juveniles in 3 habitats showed that numbers were high, though variable, in Coralline Flat habitats (areas devoid of large brown algae) but low in Ecklonia radiata forest and Deep Reef habitats. A transplant experiment was done to assess the extent to which this pattern could be ascribed to differences in juvenile survivorship among these habitats. Juveniles transplanted into Deep Reef habitats suffered a high mortality rate with a mean of $70 \%$ being dead after $18 \mathrm{wk}$, compared to only $3 \%$ for Coralline Flat habitats. Mortality in Ecklonia forest treatments was intermediate, with a mean of $37 \%$. Presence of conspecific adults did not significantly influence survivorship of juveniles in any habitat. Cause of mortality in this experiment is unknown and warrants detailed investigation. Implications of these results in the interpretation of the impact of sea urchins on benthic communities is discussed. The great variation in survivorship of juveniles in experimental situations where predators have been excluded suggests that processes other than predation are capable of strongly influencing the abundance of echinoids. The effect of conspecific adults and density on the growth of juvenile E. chloroticus was also investigated within the Coralline Flat habitat. Density of juveniles did not significantly affect their growth; however, at both densities, juveniles in the absence of adults reached a larger size than did those caged with adults.
\end{abstract}

\section{INTRODUCTION}

The observed distribution patterns of most echinoids have been explained through investigation of benthic processes, predominantly those influencing adults. From this focus has come the belief that fluctuations in the distribution and abundance of echinoids are constrained by predation (Estes \& Palmisano 1974, Mann 1977, Duggins 1980, Tegner \& Dayton 1981, Breen et al. 1982. Schroeter et al. 1983). However, the role of events during early stages of the life history in determining the patterns of distribution of benthic invertebrates has become increasingly apparent. In particular, the events prior to and during settlement have been shown to have important consequences for later patterns (e.g. Denley \& Underwood 1979, Caffey 1982, Cameron \& Rumrill 1982, Keough \& Downes 1982).

Little is known of the importance of events early in the life history in determining patterns of echinoid distribution. Settlement is generally considered to be patchy for many species (Leighton et al. 1966, Ebert

\footnotetext{
- Present address: Zoology Building, School of Biological
} Sciences, University of Sydney, NSW 2006, Australia
1968, Moore \& Lopez 1972, Dayton 1975; but see Tegner \& Dayton 1981). Variability in settlement and recruitment has usually been viewed as a modifying influence, however, rather than a sufficient explanation for patterns of abundance of adult echinoids. An exception to this view has been the work of Foreman (1977) who interpreted a temporary influx of Strongylocentrotus droebachiensis into a previously unoccupied area in the Strait of Georgia as being the result of physical factors favourable to larvae. In addition to the vagaries of settlement, differential mortality of immediately post-metamorphic juveniles may modify or determine patterns of adult distribution. Tegner \& Dayton (1977) reported that the presence of conspecific adults enhanced the survivorship of juvenile $S$. franciscanus by providing a refuge from predation. No such nursery effect was found for the New Zealand echinoid Evechinus chloroticus, nor is there any evidence suggesting that the presence of conspecific adults affects the recruitment of $E$. chloroticus within Coralline Flat habitats (Andrew \& Choat 1982). The relative importance of pre- and post-metamorphic processes has not been determined for many species. Cameron \& Schroeter (1980) have suggested, however, that events after 
settlement are more pervasive than selective settlement by larvae in determining the distribution of adult Strongylocentrotus spp.

In this paper we investigate the local patterns of distribution of juveniles of the echinometrid Evechinus chloroticus (Val.) around Goat Island, in northeastern New Zealand. The most striking feature of the distribution of E. chloroticus in northern New Zealand is the apparent restriction of dense populations to depths less than 12 m (Choat \& Schiel 1982). In habitats less than $12 \mathrm{~m}$ deep the distribution of adults is patchy. Adults may be found in large numbers within Coralline Flats, but they occur at low densities within stands of the laminarian alga Ecklonia radiata (Ayling 1981, Choat \& Schiel 1982). Here we describe the abundance patterns of juveniles in different habitats and, based on this description, we present the results of an experiment investigating aspects of these patterns. Specifically we wished to see whether, in the absence of predators, observed distribution patterns could be explained by differential survivorship of juveniles. Andrew \& Choat (1982) demonstrated that the presence of conspecific adults does not significantly influence the recruitment success of juveniles within a Coralline Flat habitat. Here we extend this to assess the influence of adults on the survivorship and growth of juveniles in other types of habitat.

\section{METHODS ANO RESULTS}

\section{Distribution of juvenile}

The survey and subsequent experiments were carried out in the immediate vicinity of Goat Island within the Cape Rodney to Okakari Point Marine Reserve, $100 \mathrm{~km}$ north of Auckland, New Zealand. The reserve has been subdivided into generalized habitat types reflecting the distribution of numerically important groups of organisms (see Leum \& Choat 1980, Ayling 1981, Andrew \& Choat 1982, Jones 1984 for descriptions).

Based on existing information on the distribution of Evechinus chloroticus, 3 types of habitat were chosen for sampling and the subsequent experiment. These habitats were: Deep Reefs, Ecklonia forests, and Coralline Flats. The Deep Reef habitat type is found at depths greater than $15 \mathrm{~m}$ and is characterized by sparse Ecklonia forests and large sponges. Ecklonia forests are dense, canopy-forming stands of the alga Ecklonia radiata. They occur at various depths; stands at between 8 and $12 \mathrm{~m}$ were used in this study. The Coralline Flats habitat type is defined as being devoid of large brown algae, with the substratum being covered with coralline algae, which is grazed by high numbers of echinoids and gastropods. Within each habitat, 3 sites were haphazardly selected in which to sample the densites of benthic organisms and to do the experimental manipulations (see Table 1). Sites within each habitat type were separated by at least $200 \mathrm{~m}$. Within each site, five $1 \mathrm{~m}^{2}$ quadrats were randomly placed and all adult E. chloroticus, herbivorous gastropods and E. radiata were counted. Within each $1 \mathrm{~m}^{2}$ quadrat, one $0.25 \mathrm{~m}^{2}$ quadrat was randomly selected and was carefully searched for juvenile E. chloroticus. The data generated by this pilot survey were used to determine the number of quadrats to be sampled within each site to give a desired degree of precision in the subsequent survey (Southwood 1978). The required number of quadrats to provide a standard error of $40 \%$

Table 1. Densities of major groups of benthic organisms in the survey. Data are presented by habitat and site within each habitat. Data as mean $\pm S E_{1} n=10$. Density of juvenile Evechinus chloroticus is per $0.25 \mathrm{~m}^{2}$, all others per $1 \mathrm{~m}^{-2}$. See text for further details

\begin{tabular}{|c|c|c|c|c|}
\hline \multirow[t]{2}{*}{ Site } & \multicolumn{2}{|c|}{ Evechinus chloroticus } & \multirow[t]{2}{*}{ Gastropods } & \multirow[t]{2}{*}{ Ecklonia radiata } \\
\hline & Adults & Juveniles & & \\
\hline \multicolumn{5}{|l|}{ Coralline Flat } \\
\hline North Reef & $1.7 \pm 059$ & $1.00 \pm 0.49$ & $33.4 \pm 5.23$ & 0 \\
\hline Knot Rock & $2.2 \pm 0.97$ & $0.70 \pm 0.42$ & $11.4=1.89$ & $0.8 \pm 0.70$ \\
\hline ' $\mathrm{c}$ & $3.2 \pm 0.93$ & $1.10 \pm 0.43$ & $3.7 \pm 1.56$ & $0.5 \pm 0.40$ \\
\hline \multicolumn{5}{|l|}{ Ecklonia forest } \\
\hline 'PB2' & 0 & 0 & $12.1 \pm 2.01$ & $13.8 \pm 1.94$ \\
\hline Moki Heaven & 0 & $0.38 \pm 0.15$ & $14.1 \pm 1.29$ & $17.1 \pm 1.62$ \\
\hline 'D' & $0.6 \pm 0.34$ & $0.10 \pm 0.10$ & $13.9 \pm 1.38$ & $18.0 \pm 1.63$ \\
\hline \multicolumn{5}{|l|}{ Deep Reef } \\
\hline Sponge Garden & 0 & 0 & $3.3 \pm 0.67$ & $3.9 \pm 1.04$ \\
\hline Porae Reef & 0 & 0 & $7.5 \pm 1.28$ & $1.9 \pm 0.83$ \\
\hline Crayfish Reef & 0 & 0 & $3.0 \pm 0.96$ & $2.7 \pm 1.05$ \\
\hline
\end{tabular}


of the mean varied with the group considered and the site being sampled. A compromise of 10 quadrats per site was used in order to balance the sampling design.

Both adult and juvenile Evechinus chloroticus were absent or at very low densities in Deep Reef and Ecklonia forest habitats (Table 1). Juveniles could be found in both habitats by systematic searchs, indicating that they did exist within these habitats. They were found in the holdfasts of Ecklonia radiata plants and around the bases of the massive sponge Ancorina alata. In the majority of instances and in all habitats, juveniles were cryptic in habit, being found in crevices and often covered with shell fragments and other debris. The density of adult $E$. chloroticus within Coralline Flats varied among sites but densities were greater than 1 per $\mathrm{m}^{-2}$ at all sites. Juvenile were present at all sites within the Coralline Flat habitat type, but, as with the adults, varied in density. Predictably, E. radiata was most abundant within Ecklonia forests, it was at intermediate density in Deep Reef habitats and was absent or rare over areas of Coralline Flat (Table 1). The inverse relation between the abundance of E. chloroticus and E. radiata described here for Goat Island Bay is in accord with the more generalized pattern described by Choat \& Schiel (1982) for northern New Zealand.

There was no such correlation between the abundance of herbivorous gastropods and either Evechinus chloroticus or Ecklonia radiata (Table 1). Gastropods, however, showed species-specific differences in abundance among habitats. For example, the limpet Cellana stellifera was not common within Ecklonia forests and was very rare within Deep Reef habitats. In general, there were fewer herbivorous gastropods in areas of Deep Reef than in the other 2 habitats.

\section{Survivorship of juveniles in relation to habitat}

An experiment was done to test 2 hypotheses: (1) that there was differential mortality of juvenile Evechinus chloroticus among the 3 habitats of interest; (2) that the presence of conspecific adults would modify the rate of that habitat-related mortality. Variability within each habitat type was assessed by repeating the experimental manipulations at 3 replicate sites; the same sites used for the sampling program were used for the experiment. The experimental design had 3 factors: 'habitat' and 'adults' were orthogonal and 'site' was nested within 'habitat'. As the manipulation of 'adults' was repeated at all sites, the factors 'site' and 'adults' were orthogonal (see Table 2 for design summary).

Cages were used to enclose the experimental sea urchins and to exclude predators. At each site, 3 cages
Table 2. Evechinus chloroticus. Analysis of variance table for the survivorship data from the transplant experiment. Both 'habitat' and 'adults' were considered to be fixed factors. Raw data were analysed. Cochran's ' $\mathrm{C}$ ' $=0.167(18 ; 2 \mathrm{df}) \mathrm{ns}$

\begin{tabular}{|c|c|c|c|c|}
\hline Source & MS & df for $F$ & $\mathrm{~F}$ & $\mathrm{p}$ \\
\hline Habitat & 55.30 & 2.6 & 18.0 & $\cdots$ \\
\hline Adults & 0.02 & 1,6 & 0.1 & ns \\
\hline Site (hab.) & 3.07 & 6,36 & 13.3 & $\cdots$ \\
\hline Hab. $\times$ ads. & 0.02 & 2,6 & 0.1 & $n s$ \\
\hline Site (hab.) $\times$ ads. & 0.23 & 6,36 & 0.2 & ns \\
\hline Residual & 1.0 & & & \\
\hline \multicolumn{5}{|c|}{$\because p=<0.01$} \\
\hline
\end{tabular}

were used within each combination of presence and absence of conspecific adults. Those cages without adults contained 8 juvenile Evechinus chloroticus alone and the 3 cages with adults contained 5 juveniles plus 3 adults. These densities were chosen as high, though realistic, densities for the species (Dix 1970).

In order to separate the effects of conspecific adults from total density in the above design an additional treatment of 5 juveniles caged alone would normally be required. This treatment was not included in this design for 2 reasons. Firstly, it has been shown that whereas density affects the growth of juvenile Evechinus chloroticus, there is no evidence for densitydependent mortality over a wide range of densities (Choat \& Andrew 1985). Secondly, a pilot experiment (Andrew 1982) had indicated that high mortality could be expected in the Deep Reef and Ecklonia forest habitats. Based on this information the treatment controlling for differences in total density (that is a cage with 5 juveniles alone) was omitted.

Cages were constructed of plastic mesh (mesh size $=18 \mathrm{~mm}$ ), with a basal area of $0.5 \mathrm{~m} \times 0.5 \mathrm{~m}$ and a height of $0.15 \mathrm{~m}$. They were attached to the substratum either with masonry nails or with bolts embedded in the substratum with an epoxy cement and hammered through polypropylene strips overlying the skirting edge of the cage. The sea urchins used in the experiment were all collected from 1 site in Goat Island Bay. They were held in running sea water while being measured and were then assigned to cages so that each cage contained specimens of similar size prior to the experiment. The juvenile Evechinus chloroticus used varied in size between 21 and $30 \mathrm{~mm}$ T.D. (test diameter). The mean size for each cage varied between 24.0 and $26.2 \mathrm{~mm}$ T.D. The adults used varied in size from 61 to $68 \mathrm{~mm}$ T.D.

The experiment ran for $18 \mathrm{wk}$ from 20 December 1983 to 16 April 1984. The cages were checked $2 \mathrm{~d}$ after the experiment began and any dead animals were 
replaced. This mortality was not confined to any particular treatment and was considered to be an artefact of the transplantation; the initial mortality was therefore not included in the estimates of survivorship. Weekly counts of the survivorship of juvenile Evechinus chloroticus were made throughout the experiment. All dead animals were replaced to maintain densities; these replacements were not included in the survivorship estimates. Replacement animals were either $5 \mathrm{~mm}$ larger than the largest experimental animal or $5 \mathrm{~mm}$ smaller than the smallest, as such they were known by size and could be excluded from analysis. At the completion of the experiment the sizes of all survivors were measured.

The greatest mortality occurred in the Deep Reef habitats where, on average, $70 \%$ of specimens died during the $18 \mathrm{wk}$ period (Fig. 1). Only 3 specimens died within the Coralline Flat treatment. The survivorship of juveniles transplanted into Ecklonia forests was intermediate; a mean of $37 \%$ of specimens were dead at the end of the experiment. Analysis of survivorship at the completion of the experiment showed that neither the presence of adults nor the interaction between 'adults' and 'habitat' significantly influenced survivorship (Table 2). There were significant differences (S.N.K. tests, $p<0.05$ ) among sites within the Deep Reef habitat where survivorship ranged from 20 to $40 \%$, and among sites in Ecklonia forest habitats where survivorship ranged from 40 to $84 \%$, but not among sites in the Coralline Flat habitat. Only 4 adult Evechinus chloroticus died during the experiment.
This mortality was not confined to any single treatment, nor was any pattern apparent in its distribution among treatments.

\section{Effect of conspecific adults on growth}

A pilot experiment (Andrew 1982) indicated that there would be very little mortality within the Coralline Flat habitat type. As a subset of the experiment described above, the growth of juvenile Evechinus chloroticus was estimated within this habitat type. In order to separate the effects of conspecific adults from total density, an abbreviated form of the design used by Underwood (1978) was used. As previously described this was done via the addition of 3 cages each containing 5 juveniles within each site. The design therefore consisted of the following treatments: 5 juveniles only, 8 juveniles only, and 5 juveniles plus 3 adults. This experiment was run over the same time period as the previous one and was maintained in the same manner.

There were significant differences in the sizes of juvenile Evechinus chloroticus both among the density treatments and among sites (Table 3). A posteriori comparisons revealed that there were no significant differences in size of juveniles between those caged at 5 per cage and those at 8 juveniles per cage (S.N.K. test). The animals in both these treatments were, however, larger than those juveniles caged with 3 conspecific adults (S.N.K. tests, $\mathrm{p}<0.05)$.

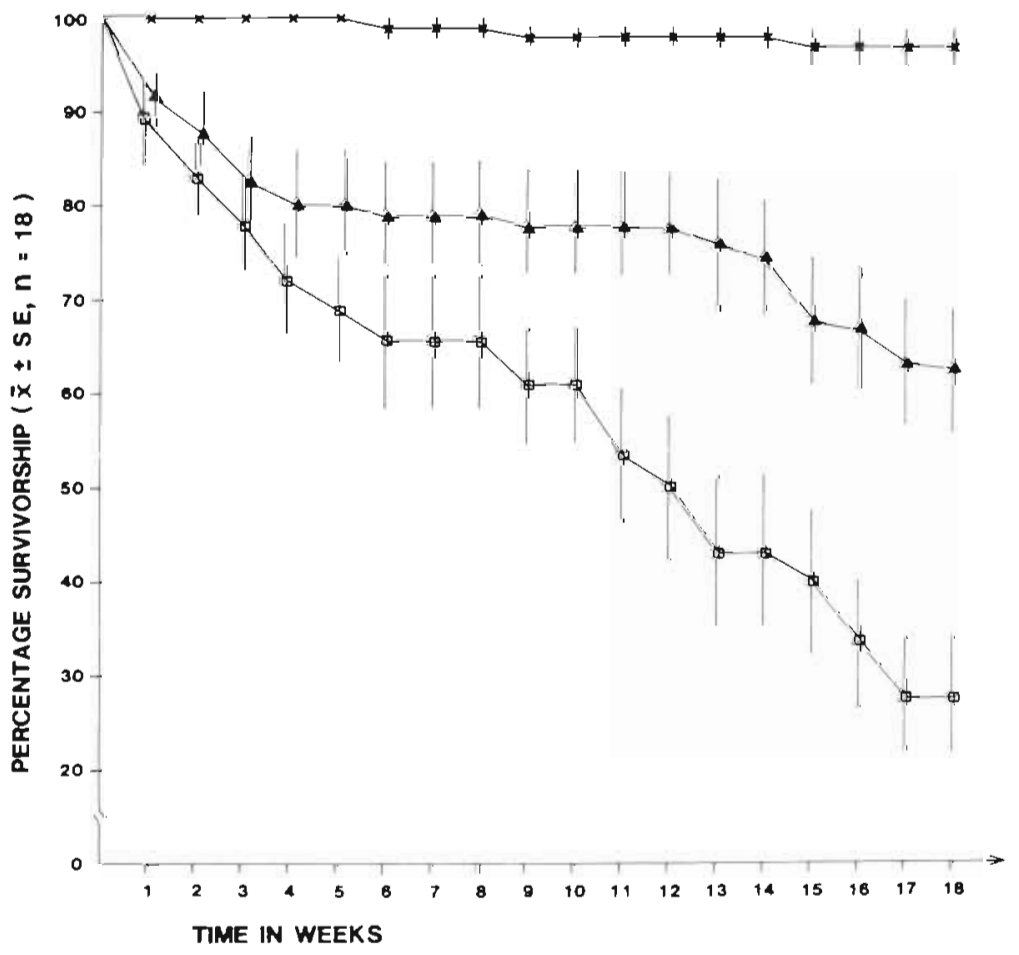

Fig. 1 Evechinus chloroticus. Survivorship of juveniles in 3 habitats. Data are pooled across the factors 'adults' and 'site'; see text for further details. Symbols: (ธ) Deep Reef; (x) Coralline Flat; (ム) Ecklonia forest 
Table 3. Evechinus chloroticus. (A) Mean size (test diameter $\mathrm{mm}$ ) of juveniles from experimental treatments within the Coralline Flat habitat type at completion of transplant experiment. Data are given by site and experimental treatment and are presented as mean $\pm \mathrm{SE}, \mathrm{n}=12$. Numbers in brackets indicate total density of juveniles per cage. (B) Analysis of variance table for above data from transplant experiment Raw data were analysed. Cochran's ' $\mathrm{C}$ ' $=0.181$ (9; $11 \mathrm{df}$ ) ns. 'Cages' was non-significant at the $\mathrm{p}=0.25$ level and was pooled into the residual (Winer 1971)

\begin{tabular}{|c|c|c|c|c|}
\hline \multirow{2}{*}{ (A) Mean size } & \multicolumn{4}{|c|}{ Experimental treatment } \\
\hline & With adults & \multicolumn{2}{|c|}{ Alone (5) } & Alone (8) \\
\hline Knot Rock & $27.8 \pm 0.65$ & \multicolumn{2}{|c|}{$31.5 \pm 0.83$} & $30.5 \pm 0.92$ \\
\hline & $28.6 \pm 0.96$ & \multicolumn{2}{|c|}{$31.4 \pm 0.69$} & $30.4 \pm 0.46$ \\
\hline North Reef & $27.1 \pm 0.65$ & \multicolumn{2}{|c|}{$29.8 \pm 0.80$} & $29.9 \pm 0.54$ \\
\hline \multicolumn{5}{|c|}{ (B) Analysis of variance } \\
\hline Source & MS & df for $F$ & $\mathrm{~F}$ & $\mathrm{p}$ \\
\hline Treatment & 110.85 & 2,4 & 33.8 & $\cdots$ \\
\hline Site & 19.59 & 2,99 & 3.7 & • \\
\hline Density $\times$ site & 3.28 & 4,99 & $0.6-6$ & ns \\
\hline Residual & 5.33 & & & \\
\hline \multicolumn{5}{|l|}{$\cdot P=<0.05$} \\
\hline \multicolumn{5}{|c|}{$\because \mathrm{P}=<0.01$} \\
\hline ns: Not significan & it at $p=0.05$ & & & \\
\hline
\end{tabular}

\section{DISCUSSION}

Both adult and juvenile Evechinus chloroticus are found at very low densities within Deep Reef and Ecklonia forest habitats. E. chloroticus is abundant within areas of Coralline Flat habitat. The results presented here indicate that juveniles caged in the former 2 habitats suffer a far faster rate of mortality than do those similarly caged on Coralline Flats, suggesting that 1 reason for the disjunct distribution of adult $E$. chloroticus and large brown algae (Choat \& Schiel 1982) is the failure of juveniles to survive in large numbers within algal stands. Similarly, failure to recruit into habitats in water deeper than $12 \mathrm{~m}$ may provide a partial explanation for the depth restricted distribution of E. chloroticus (Choat \& Schiel 1982). The actual agent of the observed mortality is unknown. Several factors such as differing levels of sedimentation among these habitats may be implicated. A preliminary survey of the sediment in Deep Reef and Coralline Flat habitats (Andrew 1982) showed that there was a greater proportional representation of finer grade sediments in the Deep Reef areas than within areas of Coralline Flat. Juvenile E. chloroticus are confined to crevices, and the accumulation of fine sands and silt in these crevices may smother them. The cause of mortality within these habitats requires more detailed investigation.

One possible explanation for the observed patterns of distribution of juvenile sea urchins is that larvae settle into these habitats initially and then die. Selective settlement away from Ecklonia forests and Deep Reefs, or presettlement mortality, would pre-empt any differential survival of postmetamorphic juveniles as a determinant of abundance. No attempt was made in the present study to assess the relative importance of mortality at larval and post-larval (settled) stages of the life history.

The great variation in survivorship of juveniles in experimental situations where predators were excluded suggests that processes other than predation are capable of exerting a strong influence on the abundance of echinoids. The presence of conspecific adults did not have a significant effect on the survivorship of juveniles. The presence of adults did, however, significantly depress the growth-rate of juveniles. The substratum in all cages containing adults was grazed down to a mosaic of encrusting coralline algae and bare rock. In cages without adults, the substratum was covered with turfing and encrusting coralline algae, and a mixed assemblage of ascidians and sponges. The relative importance of competition for food and 'crowding' effects independent of food is not known.

The high mortality of juvenile Evechinus chloroticus cages within Ecklonia forests has important implications for the interpretation of algal-echinoid interactions. Published information suggests that both the adults and juveniles of many strongylocentrotid species are found within algal stands; for example, within Nereocystis forests (Vadas 1977) and beneath Laminaria canopies (Mann 1973, Estes \& Palmisano 1974, Duggins 1980). Where juveniles are found within algal forests it is commonly considered that predation maintains densities at levels low enough to prevent the destruction of the algal stand (Estes \& Palmisano 1974. Mann 1977, Estes et al. 1978; Tegner \& Dayton 1981). The important point is that when released from predation, these species are capable of successfully recruiting into algal stands and growing to adult size in sufficient numbers to 'overgraze' the algae. Therefore, the potential exists for algal stands to be attacked from within.

The results presented here indicate that successful recruitment of Evechinus chloroticus into canopyforming stands of Ecklonia is unlikely, and that stands of Ecklonia are resistant to attack from within and may only be grazed by invasion from adjacent areas supporting high densities of $E$. chloroticus. A similar relation may exist between Macrocystis and strongylocentrotid species. Here the border between an algal stand and adjacent high densities of echinoids may remain 
stable for several years, with the densities of echinoids within the forest generally much smaller than those outside (Mattison et al. 1977, Tegner \& Dayton 1981).

Many forces will interact in a dynamic manner to determine the distribution and abundance of echinoids. Factors such as wave action (Himmelman \& Steele 1971, Cowen et al. 1982, Lissner 1983), recruitment variability (Leighton et al. 1966, Ebert 1968, Moore \& Lopez 1972, Dayton 1975), substratum heterogeneity (Lowry \& Pearse 1973, Tegner \& Dayton 1981), and disease (Pearse et al. 1977, Miller \& Colodey 1983) appear to be important. The relative importance of each will vary over local and geographic spatial scales (Cowen et al. 1982). Demonstrations of a significant influence attributable to one or several factors do not neccessarily mean than other influences are thereby excluded or not important.

Andrew \& Choat (1982) demonstrated that predation is important in determining the upper limits of abundance of juvenile Evechinus chloroticus in a Coralline Flat habitat, but argued that it was not sufficient to reduce densities to the level where large brown algae are able to recolonize the area. In this paper, we have presented results suggesting that high mortality of juveniles, independent of the actions of predators, may be important in determining the abundance of adults within Deep Reef and Ecklonia forest habitat types.

Acknowledgements. We are grateful to Jane Robertson and Laura Stocker for assistance in the field and R. G. Creese, G. P. Jones, D. R. Schiel, L. J. Stocker and A. J. Underwood for criticisms of the manuscript. We thank Dr W. J. Ballantine for support and providing the use of the University of Auckland's Marine Laboratory at Leigh. This study was funded by the University of Auckland Grants Committee.

\section{LITERATURE CITED}

Andrew, N. L. (1982). An experimental study of the distribution and abundance of Evechinus chloroticus (Echinoidea: Echinometridae). M.Sc. thesis, Univ. of Auckland

Andrew, N. L., Choat, J. H. (1982). The influence of predation and conspecific adults on the abundance of juvenile Evechinus chloroticus (Echinoidea: Echinometridae) Oecologia (Berl.) 84: 80-87

Ayling, A. M. (1981). The role of biological disturbance in temperate subtidal encrusting communities. Ecology 62: $830-847$

Breen, P. A., Carson, T A., Foster, J. B., Stewart, E. A. (1982). Changes in subtidal community structure associated with British Columbia sea otter transplants. Mar. Ecol. Prog. Ser 7: 13-20

Caffey, H. M. (1982). No effect of naturally-occuring rock types on settlement or survival in the intertidal barnacle Tesseropora rosea (Krauss). J. exp. mar Biol. Ecol. 63: 119-132

Cameron, R. A., Rumrill, S. S. (1982). Larval abundance and recruitment of the sand dollar Dendraster excentricus in Monterey Bay, California, USA. Mar Biol. 71: 197-202
Cameron, R. A., Schroeter, S. C. (1980). Sea urchin recruitment: effect of substrate selection on juvenile distribution. Mar Ecol. Prog. Ser 2: 243-247

Choat, J. H., Andrew, N. L. (1985). Interactions among species in a guild of subtidal benthic herbivores. Oecologia (Berl.) (in press)

Choat, J. H., Schiel, D. R. (1982). Patterns of distribution and abundance of large brown algae and invertebrate herbivores in subtidal regions of northern New Zealand. J. exp. mar Biol. Ecol. 60: 129-162

Cowen, R. K., Agegian, C. R., Foster, M. S. (1982). The maintenance of community structure in a central California giant kelp forest. J exp. mar. Biol. Ecol. 64: 189-201

Dayton, P. K. (1975). Experimental studies of algal canopy interactions in a sea otter dominated kelp community at Amchitka Island, Alaska. Fish. Bull. U.S. 73: 230-237

Denley, E. J., Underwood, A. J. (1979). Experiments on factors influencing settlement, survival, and growth of two species of barnacles in New South Wales. J. exp mar. Biol. Ecol. 36: 269-293

Dix, T. G. (1970). Biology of Evechinus chloroticus (Echinoidea: Echinometridae) from different localities. 1. General. N. Z. Jl mar Freshwat. Res. 4: 91-116

Duggins, D. O. (1980). Kelp beds and sea otters: an experimental approach. Ecology 61: 447-453

Ebert, T. A. (1968). Growth rates of the sea urchin, Strongylocentrotus purpuratus related to food availability and spine abrasion. Ecology 49: 1075-1091

Estes, J. A., Palmisano, J. F. (1974). Sea otters: their role in structuring nearshore communities. Science 185: $1085-1090$

Estes, J. A., Sinith, N. S., Palmisano, J. F. (1978). Sea otter predation and community organization in the western Aleutian islands, Alaska. Ecology 59: 822-833

Foreman, R. E. (1977). Benthic community modification and recovery following intensive grazing by Strongylocentrotus droebachiensis. Helgoländer Meersunters. 30: $468-484$

Himmelman, J. H., Steele, D. H. (1971). Foods and predators of the green sea urchin Strongylocentrotus droebachiensis in Newfoundland waters. Mar Biol. 9: 315-322

Jones, G. P. (1984). Population ecology of the temperate reef fish Pseudolabrus celidotus. I. Factors influencing recruitment. J. exp. mar. Biol. Ecol 75: 257-276

Keough, M. J., Downes, B. J. (1982). Recruitment of invertebrates: the role of active larval choice and early mortality. Oecologia (Berl.) 54: 348-352

Leighton, D. L., Jones, L. G., North, W. J. (1966). Ecological relationships between giant kelp and sea urchins in southern California. In: Young, E. G., McLauchlan, J. L. (ed.) Proc. 5th Int. Seaweed Symposium. Pergamon Press, Oxford, p. 141-153

Leum, L. L., Choat, J. H. (1980). Density and distribution patterns of the temperate marine fish Cheilodactylus spectabilis (Cheilodactylidae) in a reef environment. Mar Biol. 57: $327-337$

Lissner, A. L. (1983). Relationship of water motion to the shallow water distribution and morphology of two species of sea urchins. J. mar Res. 41: 691-709

Lowry, L. F., Pearse, J. S. (1973). Abalones and sea urchins in an area inhabited by sea otters. Mar. Biol. 23: 213-219

Mann. K. H. (1973). Seaweeds: their productivity and strategy for growth. Science 182: 975-981

Mann, K. H. (1977). Destruction of kelp-beds by sea urchins: a cyclical phenomenom or irreversible degradation? Helgoländer Meersunters 30: 455-467

Mattison, J. E., Trent, J. D., Shanks, A. L., Akin, T. B., Pearse, 
J. S. (1977). Movement and feeding activity of red sea urchins (Strongylocentrosus franciscanus) adjacent to a kelp forest. Mar. Biol. 39: 25-30

Miller, R. J., Colodey, A. G. (1983). Widespread mass mortalities of the green sea urchin in Nova Scotia, Canada. Mar Biol. 73: 263-267

Moore, H. B., Lopez, N. N. (1972). Factors controlling variation in the seasonal spawning pattern of Lytechinus variegatus. Mar Biol. 14: 275-280

Pearse, J. S., Costa, D. P., Yellin, M. B., Agegian, C. R. (1977). Localized mass mortality of red sea urchin, Strongylocentrotus franciscanus, near Santa Cruz, California. Fish. Bull. U.S. 75: 645-648

Schroeter, S. C., Dixon, J., Kastendiek, J. (1983). Effects of the starfish Patiria miniata on the distribution of the sea urchin Lytechinus anamesus in a southern Califinia kelp forest. Oecologia (Berl.) 56: 141-147
Southwood, T A. (1978). Ecological methods: with particular reference to insect populations, 2nd ed. Chapman \& Hall, London

Tegner, M. J., Dayton, P. K. (1977). Sea urchin recruitment and the implications of commercial fishing. Science 196: 324-326

Tegner, M., Dayton, P. K. (1981). Population structure, recruitment and mortality of two sea urchins (Strongylocentrotus franciscanus and $S$. purpuratus) in a kelp forest. Mar. Ecol. Prog. Ser. 5: 255-268

Underwood, A. J. (1978). An experimental evaluation of competition between three species of intertidal prosobranch gastropods. Oecologia (Berl.) 33: 185-202

Vadas, R. L. (1977). Preferential feeding: an optimization strategy in sea urchins. Ecol. Monogr. 47: 337-371

Winer, B. J. (1971). Statistical principles in experimental design, 2nd. ed. McGraw-Hill, Kogakusha, Tokyo

This paper was presented by Dr A. J. Southwood; it was accepted for printing on August 15, 1985 